\title{
Useful Books: \\ Community Libraries in Antebellum North Carolina
}

\author{
by Patrick M. Valentine
}

\begin{abstract}
While little has been published on libraries and print culture in the antebellum South, citizens were aware of the need to accumulate and disseminate knowledge in the form of books and magazines. North Carolina was not renowned for its schools or literary culture but it did witness over thirty attempts to establish community libraries between the American Revolution and the Civil War. This paper examines this library movement in its historical and cultural context as a reflection of the importance of print culture and voluntary associations within American civic society. By surveying a wide range of oftenneglected primary and secondary literature, this article stands as a model for further research.
\end{abstract}

Law to establish the Allemance [sic] Library Society, Guilford County:

"For the purpose of procuring and establishing a circulating Library of Useful books..."

Laws of the State of North-Carolina ... $1819^{1}$

$n$

orth Carolina, one of the original thirteen colonies, hibernated like Rip Van Winkle in a stage of seeming isolation after the American Revolution. Despite a sprinkling of towns along the coast and river valleys, the state largely remained a land of selfsufficient farmers. Women, who in later times were often great boosters of literary culture and libraries, were expected to center their lives on home while the widespread practice of black slavery corrupted cultural norms. Yet, as population grew and towns proliferated after 1800, farmers and townsmen became more tightly enmeshed in commercial society. And as transportation and communication improved, opportunities for education and cultural growth increased. Even so, Northerners as late as 1857 considered Carolinians "cultivators of turpentine rather than letters." ${ }^{2}$ This article will show, however, that libraries and literate culture did have a growing if limited place in everyday life. Both the desire to create numerous community libraries and the lack of practical result tells us much about North Carolina and the antebellum South.

Our understanding of what libraries were like at the beginning of the period would be greatly enhanced if a survey proposed by an unknown gentleman, probably the bibliophile lawyer Waightstill Avery, had been successfully carried out. He asked readers of the American Review and Literary Journal in 1802 to send particulars not only of schools and school libraries but also of "Library Companies" and any "Societies instituted for the promotion and diffusion of useful Knowledge." He wanted to know when schools and societies were established and by whom, what funds they had, their rules, members, how many books they had, and the "number of shares and their prices." An incurable optimist, he hoped to "offer his work ... in the course of the present year." 3 Unfortunately, we do not know the result, if any, of his appeal.

North Carolina had a few scattered bookstores and public reading rooms, but most people depended on printers, general stores, peddlers, and trips out of state for books. Print shops such as those of Salmon Hall in New Bern and Joseph Gales in Raleigh doubled as "circulating libraries," while Wilmington had various such stores until the 1850 s. ${ }^{4}$ Some North Carolinians sent to London or Philadelphia for books. In 1821 a "Yankee" reported that Wilmington, then the second largest town in the state, could not support a bookstore as people would "borrow" its books but forget to return them. ${ }^{5}$ Charlotte did not have systematic access to books until after 1824 when the Yorkville Book Bindery opened for business. ${ }^{6}$ A quarter century later a magazine editor still complained that merchants did not carry enough books: "The listless indifference, idle hours, crimes, punishment, widows, and orphans of our land, call for books, Books, BOOKS.”’

Peddlers were a major source of reading material in a state as rural as North Carolina, on what might be called the "cultural periphery" of America. ${ }^{8}$ Peddlers had to pay, or rather were supposed to pay, a county tax of $\$ 20$ for each "cart wagon or other vehicle" except those "who sell books only." Many peddlers, some of them Jewish, began with a small supply of goods, including books, only to end as respected and successful merchants. Peddlers often sold prints and brochures as well as books and could be sources of information and unorthodox opinion. Mason Locke Weems, the "book-peddling parson" who spread 
some of the earliest fanciful tales of George Washington, took his "Flying Library" - an early bookmobile, a wagon fitted with book shelves and waterproof top - not only to rural customers but also stopped in towns like Raleigh and Hillsborough. According to Weems, North Carolinians especially liked "great numbers of little entertaining books," while Methodist religious peddlers believed that only "about one third [sic] of the parents can read, write, cast accounts, and gauge a barrel of brandy."10

Almanacs, often locally printed, were among the most widely used books while planters and merchants might subscribe to magazines, a few of which were also locally produced. Doctors, lawyers and architects all increasingly learned their professions through reading as well as apprenticeship. Presbyterians and other Christian groups used printed tracts to spread their message. ${ }^{11}$ Commercial farming more and more relied upon agricultural journals to tell them how to grow, fertilize and market their crops. ${ }^{12}$ Access to useful books and other printed materials became increasingly important.

Among the better-known personal libraries in North Carolina were David Stone's collection of 1,400 books and Archibald D. Murphey's with over 2,000 books. Waightstill Avery early in the century owned an extensive and carefully selected library in western North Carolina while Nelson Travillion of Davie County kept a collection not just of history, biography and sermons, but also sets of morally ambiguous works such as Adulterer's Looking Glass, Drunkard's Looking Glass and Gambler's Looking Glass. The historian John Hill Wheeler had some 1,200 titles on his bookshelves in 1850, not apparently arranged in any strict order. ${ }^{13}$

These years saw a rapid growth of lyceums that sponsored debates and usually had their own libraries, yet few left records of their presence in North Carolina. Lyceums were not precisely libraries in any case. ${ }^{14}$ It is, however, indicative of the connection between libraries and lyceums that Virginia's earliest library society, the Alexandria Library Company, founded in 1794, moved into Alexandria’s new Lyceum building as a permanent resident in 1837. Many colleges also had debating societies with libraries. ${ }^{15}$

While lyceums do not seem to have been significant in North Carolina, about thirty North Carolina towns and counties did incorporate community libraries between 1794 and 1852. ${ }^{16}$ Although not in a strict sense open to the public, such libraries were emblems of literate society and tokens of community pride. They made the statement that a town recognized the social and economic as well as cultural and educational benefits a library could bestow. ${ }^{17}$

\section{Chart 1: Incorporated Community Libraries, 1790-1850}

\begin{tabular}{|l|l|l|}
\hline & \multicolumn{1}{|c|}{ Place, County } & \multicolumn{1}{|c|}{ Name } \\
\hline $\mathbf{1 7 9 4}$ & Fayetteville, Cumberland County & Fayetteville Library Society \\
\hline $\mathbf{1 7 9 9}$ & Williamsboro, ${ }^{18}$ Granville County & Franklin Library Society \\
\hline $\mathbf{1 8 0 3}$ & New Bern, Craven County & Newbern Library Society \\
\hline $\mathbf{1 8 1 5}$ & Person County & Person Library Company \\
\hline $\mathbf{1 8 1 6}$ & Raleigh, Wake County & Raleigh Library Company \\
\hline $\mathbf{1 8 1 7}$ & Iredell County & Centre Library Society \\
\hline $\mathbf{1 8 1 8}$ & (Buffalo Knob?) Lincoln County & Buffalo Library Society? \\
\hline $\mathbf{1 8 1 8}$ & Fayetteville, Cumberland County & Fayetteville Library Company \\
\hline $\mathbf{1 8 1 9}$ & New Salem, Randolph County & Salem Library Society \\
\hline $\mathbf{1 8 1 9}$ & (Alamance Church?) Guilford County $^{\text {Alate }}$ & Allemance Library Society \\
\hline $\mathbf{1 8 2 0}$ & Randolph County & Carraway Library Society \\
\hline $\mathbf{1 8 2 1}$ & Union Grove, Iredell County & Union Library Society \\
\hline $\mathbf{1 8 2 2}$ & Richland Creek, Guilford County & Richland Creek Library Society \\
\hline $\mathbf{1 8 2 2}$ & Hillsborough, Orange County & Franklin Library Society ${ }^{19}$ \\
\hline $\mathbf{1 8 2 3}$ & Mecklenburg County & New Providence Library Company \\
\hline $\mathbf{1 8 2 3}$ & Davidson County & Sandy Creek Library Society \\
\hline $\mathbf{1 8 2 4}$ & Stokes County ${ }^{20}$ & Clinton Library Society \\
\hline $\mathbf{1 8 2 5}$ & Northampton County & Farmers' Library Society \\
\hline $\mathbf{1 8 2 5}$ & Greensboro, Guilford County & Greensboro Library Society \\
\hline $\mathbf{1 8 2 5}$ & Abbott's Creek, Davidson County & Abbott's Creek Library Society \\
\hline
\end{tabular}




\begin{tabular}{|l|l|l|}
\hline $\mathbf{1 8 2 6}$ & Lincoln County & Buffalo Library Society \\
\hline $\mathbf{1 8 2 6}$ & Randolph County ${ }^{21}$ & Ebenezer Library Society \\
\hline $\mathbf{1 8 2 7}$ & New Garden, Guilford County & New Garden Library Society \\
\hline $\mathbf{1 8 2 7}$ & Nazareth, Guilford County & Guilford County (Nazareth?) Library Society \\
\hline $\mathbf{1 8 2 7}$ & Hookerton, Greene County & Hookerton Library Society \\
\hline $\mathbf{1 8 2 9}$ & Asheville, Buncombe County & Vance Circulating Library Society ${ }^{22}$ \\
\hline $\mathbf{1 8 3 1}$ & Lenoir County & United Brothers' Library Society \\
\hline $\mathbf{1 8 3 3}$ & Hookerton, Greene County & Hookerton Library Society \\
\hline $\mathbf{1 8 3 3}$ & Chatham County & Farmers' Library Association \\
\hline $\mathbf{1 8 3 4}$ & Providence, Mecklenburg County & Juvenile Library Society of Providence \\
\hline $\mathbf{1 8 4 1}$ & Fayetteville, Cumberland County & Franklin Library Institute \\
\hline $\mathbf{1 8 4 5}$ & Fayetteville, Cumberland County & Fayetteville Library Institute \\
\hline $\mathbf{1 8 4 8}$ & Williamston, Martin County & Williamston Library Association \\
\hline
\end{tabular}

This list does not include lyceums or literary and debating societies that may well have had book collections or encouraged the collecting and sharing of books. Nor does it include unincorporated libraries like one apparently active in Tarboro in eastern North Carolina before the turn of the century. ${ }^{23}$ Several, indeed most, of these library societies are completely unknown other than their being incorporated by the legislature. As can be readily seen, some of these groups were re-incorporated later and a few may have been more pious wishes or town boosterism than actual libraries. Fayetteville, for example, had been passed over as the state capital but still wanted in 1794 to attract attention as a more refined location than the almost unpopulated area chosen near a tavern in Wake County. Incorporation did, however, establish a legal and historical record of the desire to form a library, not just a society.

Such societies were usually already active before requesting incorporation. For example, "sundry persons, citizens of the county of Iredell, have associated together and formed a circulating Library, for the purpose of disseminating useful knowledge." It is also probable that many were created in imitation of earlier communities, just as Raleigh would later open a public library in imitation of Durham. ${ }^{24}$ Who these people were and the rules for membership in the library societies is usually not recorded but they seem to have been similar to the "farmers, mechanics, Justices of the Peace, ministers of the Gospel - Military Officers, Lawyers, School masters - merchants - postmasters" mentioned in a letter to Thomas Jefferson about the Westward Mill Library Society of New Brunswick County, Virginia. ${ }^{25}$ Library societies allowed for a generous membership of local white males, and perhaps females too, and as such were as close to "public" libraries as there were in this period outside of New England. In places where more evidence has survived, non members could typically borrow by paying a small fee. ${ }^{26}$

Almost all the incorporations stated that "disseminating useful knowledge" was a primary goal. However, since the records of almost none of these libraries have survived, it is also impossible to know if "useful knowledge" was disseminated. Promoting access to "useful knowledge" was surely a public good in a progressive society. ${ }^{27}$ The problem was that the institutional or communal basis for public access was always extremely limited in practice. There is moreover the question whether the South by the late 1850 s was interested in promoting a progressive or knowledge-based society. ${ }^{28}$

The general sense of the term "useful knowledge" suggests these local societies were interested in practical books rather than belles lettres and that they were not indulging in an ideology or false consciousness of pretension. The phrase "useful knowledge" was widely used in library circles in England and America. Library society members, to use terms not yet invented, were "middlebrow," not "highbrow". The lack of detailed information about these libraries, however, precludes authentic reconstruction of their mentality. ${ }^{29}$

Almost the only thing known, for instance, about the Williamston Library Association founded in 1848 is that Cushing Biggs Hassell, himself irregularly educated but an important Primitive Baptist minister and leader, was its secretary-treasurer. In only one case does state law mention the demise of a library society, in Person County, apparently because the association owned property that had to be distributed. ${ }^{30}$

The two best-documented library situations were Fayetteville and New Bern. The state's first incorporated library group was 
the Fayetteville Library Society in 1794. It set the legal pattern. Some laws included names of the petitioners but most did not:

"That the present members of the Fayetteville Library Society, and all persons who may hereafter be admitted into the same, be, and are hereby constituted, a body corporate by the name of the Fayetteville Library Society; and by that name shall have succession, sue and be sued, and may purchase and convey property, and make bye-laws and regulations in all matters relating to the objects of their association, provided the same are not inconsistent with the laws and constitution of the state."

Nothing more is known about this Society. ${ }^{31}$

In 1818 local citizens "actuated by the desire of disseminating useful Knowledge" next incorporated the Fayetteville Library Company. They paid a $\$ 10$ initiation fee with annual dues thereafter of $\$ 1.00$. How long this library survived is not clear, but there appears to have been three additional libraries in Fayetteville in the 1840s. The first was the Franklin Library Institute of 1841 and the second was the Fayetteville Library Institute in $1845 .{ }^{32}$ Little is known of these libraries and their existence seems forgotten.

Meanwhile, the Independent Order of Odd Fellows operated a Fayetteville library from 1844 until 1877, but strictly speaking this was a society but not a community library. There were a large number of similar associations across the state, Odd Fellows and Masons as well as several Mechanics' Associations that may have had libraries. Thus, leaving aside private, church and school libraries, Fayetteville alone witnessed at least five attempts to create community or society libraries between 1794 and the Civil War. ${ }^{33}$

To turn to New Bern, North Carolina's largest town before 1840, Frederick Grist, its legislative representative, sponsored the incorporation of the Newbern Library Society at the end of 1803. This was probably in response to the conditions set in Thomas Tomlinson's will that left 100 pounds, a princely sum, towards establishing public libraries in New Bern and in Wigton, County of Cumberland in Great Britain. The Newbern Library soon sold an additional eighty shares at $\$ 20$ each. John Louis Taylor and William Joseph Gaston, later both highly respected justices of the North Carolina Supreme Court, were early library presidents. ${ }^{34}$

Salmon Hall, a printer and bookseller who had moved to New Bern from Connecticut in 1800 when he was 28 years old, seems to have been the principal spirit behind the Newbern Library Society, in a manner very similar to the situation in the exactly contemporary Library Society in Georgetown, South Carolina. According to its by-laws, "members may detain [keep] a folio one month, a quarto three weeks, an octavo a fortnight, a duodecimo or pamphlet one week." Overdue fines also varied according to the size of the book, with Hall receiving the money as compensation for his labors. ${ }^{35}$

Purchases included old standards like Amadis of Gaul in four volumes (1818) bound for \$1.60; and new works like the story of the Lewis and Clark expedition (1820) $\$ 50$, bound for $\$ 1.25$ - for most books were still sold without covers and buyers could have books bound as they wished. In June 1823, thirty of forty-one library stockholders met to check accounts and to forfeit shares of "such stockholders as have not complied with the [annual] registration . . o of four dollars on each share." A catalog of 1829 lists 207 titles, many of them law books, but also including philosophy and history. The last meeting recorded was in 1835 when new directors were appointed. As the saga of this library indicates, New Bern remained culturally important in North Carolina well into the nineteenth century despite its fading economic situation and loss of political power. ${ }^{36}$

Hookerton in Greene County, much smaller than New Bern or Fayetteville, was ambitious enough to try incorporating a library twice, in 1827 and 1833. Hookerton earlier had an academy in the 1810s with a school library apparently open to public use. Lincoln County also incorporated its library twice. Or to cite another example, it is symptomatic of the obscurity to which these library efforts sank, that a good history of Guilford College, which grew out of the New Garden Boarding School, makes no mention of the earlier New Garden Library Society. ${ }^{37}$

In 1819 the legislature empowered the New Salem Library Society near New Garden, between Asheboro and Greensboro, "to 
purchase one acre of land ... and erect such buildings thereon as may be deemed necessary." ${ }^{38}$ New Salem was briefly home to the remarkable Swaims. Benjamin Swaim, president of the North Carolina Manumission Society after 1827, wrote a number of law books and edited a newspaper while building up a fine private library of his own. His cousin William Swaim, son of a substantial landowner, had enough schooling as a child-two months' worth in an old field school and another two months of intermittent schooling when he was eighteen-to learn to read but was twelve before he learned to write. His diary mentions a community circulating library that helped him "learn about all subjects." This must have been the New Salem Library Company. William took up printing in Baltimore and enjoyed the city library there before returning to North Carolina and starting his own newspaper in 1829. "His editorials were fearless in their attacks, sparkling with wit and humor or burning with sarcasm," says his biographer. He died young but not before having a daughter who would become the mother of William Sydney Porter, better known as O. Henry. ${ }^{39}$

That Providence in Mecklenburg County near Charlotte-probably Providence Presbyterian Church-started a children's library in 1834 is most intriguing. ${ }^{40}$ Possibly some other communities or churches had similar, if less documented, juvenile libraries. Obtaining a legislative charter might not be difficult, but also would not be simple. The legislature ceased requiring special legislation in 1852, after which no new incorporated libraries were recorded. ${ }^{41}$

Wilmington, which became the state's largest town by 1850, started an unincorporated Wilmington Mercantile Library Association in 1849 with evidently little success. Significantly, however, it became part of the Wilmington Library Association formed six years later. "All donations of Books, Maps, Charts, Engravings, Paintings or Plaster Casts of eminent persons must be directed to Mr. J. J. Norcom, Librarian. Editors of Magazines and papers throughout the country are asked to send copies of their publications." In 1858 the library moved into the newly completed city hall where it soon proposed to be open every day for six hours. But at the end of the Civil War the books were scattered and lost. ${ }^{42}$

Men could join the Wilmington Library Association for five dollars with an annual subscription of four dollars. Members would bind and donate such British magazines as Chamber's Journal, Blackwood's Magazine and the Edinburgh Review while many Wilmington readers enjoyed Dickens, Thackeray and "whispered about" Emerson. The Association also sponsored public lectures with speakers from outside Wilmington. The library, admitted the niece of one of its prominent members, was more a public forum for the "exchange of ideas than a visible agency for dissemination of knowledge . . . for . . . all the educated people know each other, and were united by all the ties of a vigorous mental life." Thus it might be considered an example of a library as a public sphere or agency of culture. ${ }^{43}$

These community libraries appear to be very scattered but some statistics may add to the picture. According to the 1850 Census, North Carolina had four public libraries with a total of 2,500 volumes: Craven County (probably the Newbern Library Society) with 700 books, Guilford County (where there were possibly five incorporated Library Societies) with 1,500 books, Martin County (probably the Williamston Library) with 250 books, and Randolph County (three possible Library Societies) with fifty books. Census statistics are not necessarily accurate-Fayetteville and Wilmington are conspicuous in their absence-but do indicate a general level of activity. Still, North Carolina compares very unfavorably with its two neighboring states.

\section{Chart 2, Comparative Public Library Statistics, 1850 $^{44}$}

\begin{tabular}{|l|c|c|c|c|}
\hline State & $\begin{array}{c}\text { White } \\
\text { Population }\end{array}$ & $\begin{array}{c}\text { \# of Public } \\
\text { Libraries }\end{array}$ & Public Library Volumes & $\begin{array}{c}\text { Public Library Volumes } \\
\text { /White Population }\end{array}$ \\
\hline NC & 553,028 & 4 & 2,500 & 0.005 \\
\hline SC & 274,563 & 16 & 73,758 & 0.269 \\
\hline VA & 894,800 & 21 & 32,595 & 0.036 \\
\hline
\end{tabular}

According to the 1860 census, North Carolina had two more libraries than in 1850, but 600 less books. The census counted 1,936 teachers, 1,266 physicians, 500 lawyers, 205 printers and publishers, 48 editors, 57 peddlers, sixteen booksellers and bookbinders, eight telegraph operators, and only two librarians. It is just not true, at least of North Carolina, that the number of libraries "increased dramatically" in the antebellum South. ${ }^{45}$ 
Chart 3, Comparative Public Library Statistics, 1860 $^{46}$

\begin{tabular}{|l|c|c|c|c|}
\hline & $\begin{array}{c}\text { White } \\
\text { Population }\end{array}$ & $\begin{array}{c}\text { \# of Social } \\
\text { (i.e., public) } \\
\text { Libraries }\end{array}$ & $\begin{array}{c}\text { Social } \\
\text { (i.e., public) } \\
\text { Library Volumes }\end{array}$ & $\begin{array}{c}\text { Social (i.e., public) } \\
\text { Library Volumes } \\
\text { /White Population }\end{array}$ \\
\hline NC & 629,942 & 6 & 1,950 & 0.003 \\
\hline SC & 291,300 & 18 & 31,615 & 0.109 \\
\hline VA & $1,047,299$ & 30 & 15,956 & 0.015 \\
\hline
\end{tabular}

Nonetheless, if one looks at comparative regional statistics for the antebellum period, the South was making progress. Counting all known libraries except private and school, historian Haynes McMullen found that the cumulative number of southern libraries grew from forty-one in 1800 to 100 in 1820 , to 213 in 1840 and 372 in 1860 - but many of these were very shortlived or, as we have seen, only on paper. The South's percentage of growth outpaced the Northeast's - which started with a far larger number of libraries - yet was less than the Midwest or the West. What might have happened if war - as in the 1770s - not intruded? The South was not as widely or highly literate as New England but hardly Emerson's "culture of no mind." ${ }^{47}$

Chart 4, Library regional statistics, $1800-1860^{48}$

\begin{tabular}{|c|c|c|c|c|c|c|c|c|c|c|c|}
\hline & & & & Northeast & Northeast & & South & South & & Other & Other \\
\hline & & $\%$ & & $\%$ & $\%$ & & $\%$ & $\%$ & Other & $\%$ & $\%$ \\
\hline & U.S. & Change & Northeast & U.S. & Change & South & U.S. & Change & Regions & U.S. & Change \\
\hline 1800 & 413 & & 365 & $88 \%$ & & 41 & $10 \%$ & & 7 & $2 \%$ & \\
\hline 1820 & 633 & $153 \%$ & 500 & $79 \%$ & $137 \%$ & 100 & $16 \%$ & $244 \%$ & 33 & $5 \%$ & $471 \%$ \\
\hline 1840 & 1,108 & $175 \%$ & 737 & $67 \%$ & $147 \%$ & 213 & $19 \%$ & $213 \%$ & 158 & $14 \%$ & $479 \%$ \\
\hline 1860 & 2,211 & $200 \%$ & 1,078 & $49 \%$ & $146 \%$ & 372 & $17 \%$ & $175 \%$ & 761 & $34 \%$ & $482 \%$ \\
\hline
\end{tabular}

While some Southerners feared books and the thoughts that books might enkindle, particularly thoughts of political reform and emancipation, other Southerners strove to found community libraries and increase access to books, magazines and other printed materials. ${ }^{49}$ The antebellum period saw many North Carolina communities incorporate libraries in their effort to promote education and spread useful knowledge. They were a significant Southern example of the American tendency to form voluntary associations to serve public needs. ${ }^{50}$ North Carolina, as these libraries indicate, was no longer Rip Van Winkle. People spread across the state recognized that community libraries could be useful. Libraries, or at least the concept of libraries, were slowly making their mark as places symbolic of public literacy and community interest.

\section{Refrences}

${ }^{1}$ (Raleigh: Tomas Henderson, Jr., 1820), 72-73. Background material and bibliographies are in Wiley J. Williams, "History of North Carolina Libraries and Librarianship: A Bibliography," North Carolina Libraries 62 (2004): 50-58, 91-100, 140-160, 194-215; Patrick M. Valentine, "Libraries and Print Culture in Early North Carolina," North Carolina Historical Review [cited hereafter as NCHR] 83 (July 2005): 293-325; and David Finkelstein and Alistair McCleery, An Introduction to Book History (New York: Routledge, 2005).

${ }^{2}$ Clyde Wilson, "Griffith John McRee: An Unromantic Historian of the Old South," NCHR 47 (January 1970): 14 (quotation); cf. Frances Ann Kemble, Records of Later Life (New York: Henry Holt, 1883), 111-16; Amelia M. Murray, Letters from the United States, Cuba and Canada (New York: G.P. Putnam, 1856, 2 vols. in one), 192; J. Dickson to John A. Dickson, 30 March 1844, Dickson Family Papers, Southern Historical Collection, University of North Carolina Wilson Library [cited hereafter as SHC]; and John Gray Bynum to Thomas Ruffin, J.G. de Roulhac Hamilton, ed., The Papers of Thomas Ruffin, 4 vols. (Raleigh: Edwards \& Broughton, 1918-1920), 2:200. See also William S. Powell, North Carolina Through Four Centuries (Chapel Hill: University of North Carolina Press, 1989); Guion Griffis Johnson, Ante-Bellum North Carolina: A Social History (Chapel Hill: University of North Carolina Press, 1937); Arthur C. Menius III, "James Bennitt: Portrait of an Antebellum Yeoman," NCHR 58 (October 1981): 320-22; and Bertram Wyatt-Brown, The Shaping of Southern Culture: Honor, Grace and War, 1760s-1880s (Chapel Hill: University of North Carolina Press, 2001). For women see Margaret Supplee Smith \& Emily Herring Wilson, 
North Carolina Women Making History (Chapel Hill: University of North Carolina Press, 1999), 79-81, 83, 103; Christine Leigh Heyrman, Southern Cross: The Beginnings of the Bible Belt (Chapel Hill: University of North Carolina Press, 1997), esp. 167-205. On slavery, see especially Ira Berlin, Generations of Captivity: A History of African-American Slaves (Cambridge: Harvard University Press, 2003); and Jeffrey J. Crow, Paul D. Escott and Flora J. Hatley, A History of African Americans in North Carolina, rev. ed. (Raleigh: Office of Archives and History, North Carolina Department of Cultural Resources, 2002). ${ }^{3}$ W. S. A., "Literary History of North-Carolina," The American Review and Literary Journal for the year 1802, 2 (New York): 375-79; cf., Raleigh Register and North-Carolina Gazette, September 7, 1802. Dictionary of North Carolina Biography [cited hereafter as DNCB]), s.v. "Avery, Waightstill”; SHC, Avery Family Papers; and "Biographical Sketch of Waightstill," North Carolina University Magazine, 4 (1855): 242-264.

${ }^{4}$ North Carolina Circular and Newbern Weekly Advertiser, October 28, 1803, February 24, 1804, September 21, 1804; Laws of the Raleigh Academy ... as revised, in the year 1811 (Raleigh: Gales \& Seaton, 1811). Neither David Kaser, A Book for a Sixpence: The Circulating Library in America (Pittsburgh: Beta Phi Mu, 1980), 1-17; nor Mary Virginia Moore, "Circulating Libraries in the Southeastern United States, 1762-1842” (master's thesis, University of North Carolina at Chapel Hill, 1958), cite any North Carolina locations.

${ }^{5}$ Robert J. Parker, "A Yankee in North Carolina: Observations of Thomas Oliver Larkin, 1821-1826," NCHR 14 (October 1937): 329; see also Anon., "William Soranzo Hasell," North Carolina University Magazine 7 (February 1858): 264; and Thomas Hall Wetmore, "The Literary and Cultural Development of Ante-Bellum Wilmington" (master's thesis, Duke University, 1940).

${ }^{6}$ Catawba Journal, December 7, 1824, and February 1, 1825.

${ }^{7}$ Southern Index (Ashborough) 1 (May 1850): 26 (quotation). For a somewhat dated work on reading and the availability of books, see Clyde Hull Cantrell, "The Reading Habits of Ante-Bellum Southerners" (PhD diss., University of Illinois, 1960).

${ }^{8}$ Peter Burke, Popular Culture in Early Modern Europe (New York: Harper Torchbooks, 1978), 14 (quotation). The literature on book peddling is scattered but see, inter alia, William J. Gilmore, Reading Becomes a Necessity of Life: Material and Cultural Life in Rural New England, 1780-1835 (Knoxville: University of Tennessee Press, 1989), 175-78; and Henri Jean Martin et al., eds., Histoire de l'Edition Française, 4 vols. (Paris: Promodis, 1984-1985), 2:430-43; 3:228-60.

${ }^{9}$ The Laws of the State of North-Carolina 1819 (Raleigh: Thomas Henderson, Jr., 1820), chapter i.

${ }^{10}$ Lewis Leary, The Book-Peddling Parson: An Account of the Life and Works of Mason Locke Weems... (Chapel Hill: Algonquin Books, 1984), 22-25, 60, 142-145 (quotation, 25). "Reports of Colporteurs in North Carolina," Twenty-ninth Annual Report (North Carolina Methodist Conference, 1854), Report of Mr. J. N. A., 108 (quotation), Special Collections, Duke University Perkins Library [cited hereafter as Duke SC]. See also "Weem's Writings," Southern Index 1 (March 1850): 3. For Jewish merchants, see citations in Patrick M. Valentine, The Rise of a Southern Town: Wilson, North Carolina, 1849-1920 (Baltimore: Gateway Press, 2002), 26.

${ }^{11}$ Thomas B. Jones, "Calvin Jones, M.D.: A Case Study in the Practice of Early American Medicine," NCHR 49 (January 1972): 56-71; Thomas G. Dyer, "Science in the Antebellum College: The University of Georgia, 1801-1860," in Ronald L. Numbers and Todd L. Savitt, eds., Science and Medicine in the Old South (Baton Rouge: Louisiana State University Press, 1989), 36-54; Fannie Memory Farmer, "Legal Education in North Carolina, 1820-1860," NCHR 28 (July 1952): 294-95. See also, for example, Hamilton, ed., Papers of Thomas Ruffin, 2:35, 3:458; The American (Fayetteville), July 23, 1818; North Carolina Argus (Fayetteville), December 30, 1854. Annual Report of the Raleigh Female Tract Society (Raleigh: J. Gales, 1820), 4-5; Mrs. John (Elisa Williams) Haywood in the Haywood Family Papers, SHC; Isiah F. Hollister to Mrs. Williana W. Lacy, June 23, 1838, Drury Lacy Papers, SHC; Johnson, Ante-Bellum North Carolina, 810-12; Richard Rankin, Ambivalent Churchmen and Evangelical Churchwomen: The Religion of the Episcopal Elite in North Carolina, 1800-1860 (Columbia: University of South Carolina, 1993), 40-41, 43, 47; and David Paul Nord, Faith in Reading: Religious Publishing and the Birth of Mass Media in America (New York: Oxford University Press, 2004).

${ }^{12}$ Wesley Herndon Wallace, “North Carolina’s Agricultural Journals, 1838-1861,” NCHR 33 (July 1959): 275-306; Richard Bardolph, "A North Carolina Farm Journal of the Middle 'Fifties," NCHR 25 (January 1948): 57-89; George Stevenson's Commencement address of 1855 in George Washington Paschal, History of Wake Forest College (Wake Forest: Wake Forest College, 1935), 580-81.

${ }^{13}$ DNCB, s.v. "Stone, David"; William Henry Holt, ed., The Papers of Archibald D. Murphey, 2 vols. (Raleigh: E.M. Uzzell, 1914), 2:438-42; Jethro Rumple, History of Rowan County, North Carolina... (1881; reprint, Bowie, Md: Heritage Books, 1999), 192. SHC 1948-z, Nelson Travillion papers; "Catalogue of Library June 1850," John H. Wheeler Papers, SHC. See also David S. Reynolds, Beneath the American Renaissance: The Subversive Imagination in the Age of Emerson and Melville (Cambridge: Harvard University Press, 1988), 59-61; Clement Eaton, The Growth of Southern Civilization, 1790-1860 (New 
York: Harper, 1953), 153; Clement Eaton, The Waning of the Old South Civilization 1860-1880s (Athens: University of Georgia Press, 1968), 42-44, 177; and Wetmore, "Literary and Cultural Development of Ante-Bellum Wilmington," esp. 40 and 55.

${ }^{14}$ Proceedings of the Jackson Lyceum Society, 1838-1839, David Alexander Barnes papers, SHC. Cf., American Lyceum; with the Proceedings of the convention, held in New York, May 4, 1831... (Boston: Hiram Tupper, 1831), 12; Address of the Literary and Philosophical Society of South-Carolina... (Charleston: Observer Office Press, 1834), esp. 7, 9, 41, 49, 52; William S. Powell, When the Past Refused to Die: A History of Caswell County ... (Durham: Moore Publishing, 1977), 321; and Jonathan Daniel Wells, The Origins of the Southern Middle Class (Chapel Hill: University of North Carolina Press, 2004), 91-105.

${ }^{15}$ David Scott Turk, "For the Love of Books: Antebellum Libraries Companies in Virginia," Virginia Cavalcade 49 (Winter 2000): 30-39; Patrick M. Valentine "Small Select Library or Miserable Excuse: Antebellum College Libraries in the American Southeast," Southeastern Librarian, 54 (Spring 2006): 6-11

${ }^{16}$ By comparison, South Carolina had forty-one incorporated libraries by 1860. Roberta VH. Copp, "South Carolina Library Societies: 1800-1900: The Foundation of South Carolina's Public Library System," South Carolina Librarian 30 (Spring 1986): $17-25$.

${ }^{17}$ On public libraries in this formative period, see McMullen, American Libraries before 1876, esp. 63-79; and C. Seymour Thompson, Evolution of the American Public Library 1653-1876 (Washington, D.C.: Scarecrow Press, 1952), 2, 76-79. Even Franklin's Library Company, housed in Pennsylvania's State House, had a "public" or community function. "At the Instance of Benjamin Franklin" A Brief History of the Library Company of Philadelphia (Philadelphia: Library Company of Philadelphia, 1995), 10-13, 25, 38-39.

${ }^{18}$ Williamsboro became part of Vance County in 1881. Samuel Thomas Peace, 'Zeb's Black Baby,'Vance County North Carolina (Durham: Seeman Printing, 1955).

${ }^{19}$ Three years later the Franklin Library Society petitioned unsuccessfully to start a lottery for "the purchase of useful books." Charles L. Coon, The Beginnings of Public Education in North Carolina (Raleigh: Edwards and Broughton, 1908, 1:289.

${ }^{20}$ One local observer noted in 1846 that "in general education is looked upon as a curse." Quoted in Bill Sharpe, $A$ New Geography of North Carolina (Raleigh: Sharpe Publishing, 1965), 2079.

${ }^{21}$ Ebenezer Library Society was formed "for the purpose of promoting religion and aiding the progress of learning and science" with such powers necessary "for the management and safe-keeping of the books and other property of said society, as they may from time to time think expedient, not inconsistent with the Constitution and laws of this State, or of the United States." No exact location was specified. Acts Passed by the General Assembly of the State of North Carolina ... 1826 (Raleigh: Lawrence \& Lemay, 1827), chap. xxxix.

${ }^{22}$ This was the only library named after an individual, "in honor of their patron Robert B. Vance." Acts of the General Assembly of the State of North Carolina, ... 1829-30 (Raleigh: Lawrence Lemay, 1830), chap. lxvi. Robert Brack Vance died in a duel with a legislative opponent. He left some 500 books that started the Vance Circulating Library. James Meehan, "Duelist's Legacy Started a Library," The State [Magazine] (March 1973): 14-16; DNCB, "Vance, Robert Brack;" and Gordon McKinney, Zeb Vance: North Carolina's Civil War Governor and Gilded Age Political Leader (Chapel Hill: University of North Carolina Press, 2004), 12.

${ }^{23}$ Jeremiah Battle, “The County of Edgecombe in 1810," University of North Carolina Magazine, 10 (April 1861) 470 (originally published in 1811).

${ }^{24}$ Laws of North-Carolina ... 1821, lxxvi. Patrick M. Valentine, "Steel, Cotton, and Tobacco: Philanthropy and Public Libraries in North Carolina, 1900-1940," in Donald G. Davis, Jr., ed., Libraries \& Philanthropy (University of Texas at Austin Press, 1996), 272-98; and Valentine, "The Spread of Public Libraries ... in North Carolina, 1900-1960," North Carolina Libraries 54 (Fall 1996): 113-21.

${ }^{25}$ John Wyche to Thomas Jefferson, March 19, 1809, Bixby Collection, Missouri Historical Society, St. Louis, as cited in Joyce Appleby, Inheriting the Revolution: The First Generations of Americans (Cambridge: Harvard University Press, 2000), 239.

${ }^{26}$ The Petersburg Library Association, chartered in 1853, had several female members. Edward A. Wyatt IV, "Schools and Libraries in Petersburg, Virginia, prior to 1861," Tyler's Quarterly Historical and Genealogical Magazine 19 (1937): 80. Edgefield in South Carolina had a separate Female Library Society. North Carolina had several women's association such as the Dorcas about which little is known.

${ }^{27}$ Patrick Wilson, Public Knowledge, Private Ignorance: Toward a Library and Information Policy (Westport, Conn.: Greenwood Press, 1977); Richard D. Brown, Knowledge Is Power: The Diffusion of Information in Early America, 1700-1865 (New York: Oxford University Press, 1989); Joel Mokyr, The Gifts of Athena: Historical Origins of the Knowledge Economy (Princeton: Princeton University Press, 2002); and Anne C. Rose, Voices of the Marketplace: American Thought and Culture 1830-1860 (Lanham, Md: Rowman and Littlefield, 2004 ed.), 84-87. 
${ }^{28}$ Michael O'Brien, Re-Thinking the South: Essays in Intellectual History (Athens: University of Georgia Press, 1993), 1-56; Thomas S. Harding, College Literary Societies: Their Contributions to Higher Education in the United States 1815-1876 (New York: Pageant Press, 1971), 194; and Wyatt-Brown, The Shaping of Southern Culture. For black Americans' appreciation of "useful knowledge," see Elizabeth McHenry, Forgotten Readers: Recovering the Lost History of African American Literary Societies (Durham: Duke University Press, 2002), 96-97.

${ }^{29}$ Russel B. Nye, Society and Culture in America, 1830-1860 (New York: Harper \& Row, 1974), 35-36; Alistair Black, A New History of the English Public Library: Social and Intellectual Contexts, 1850-1914 (London: Leicester University Press, 1996); John B. Thompson, Ideology and Modern Culture: Critical Social Theory in the Era of Mass Communication (Stanford: Stanford University Press, 1990); Lawrence W. Levine, Highbrow / Lowbrow: The Emergence of Cultural Hierarchy in America (Cambridge: Harvard University Press); and Emily B. Todd, "Antellum Libraries in Richmond and New Orleans and the Search for the Practices and Preferences of 'Real' Readers," in Thomas Augst and Wayne A. Wiegand, eds., The Library as an Agency of Culture, American Studies 42 (Fall 2001): 195-209. One careful historian admits that, where there is evidence, its "net effect is to leave one doubtful of the accuracy of contemporary reports about the libraries." John Calvin Colson, "The Fire Company Library Associations of Baltimore, 1838-1858," Donald G. Davis, Jr., ed., Libraries, Books \& Culture (Austin: University of Texas at Austin, 1986), 166.

${ }^{30}$ Cushing Biggs Hassell diary, SHC; Cushing Biggs Hassell Papers, Duke SC; William Bagley Papers, SHC; Williamston Academy papers, State Archives. On the Primitive Baptists, see Arthur Carl Piepkorn, "The Primitive Baptists of North America," Concordia Theological Monthly 42 (1971), 297-314. Laws of North Carolina... 1815 (microfiche, N.C. State Library), chap. lxvii; Acts of the General Assembly of North Carolina, passed ... 1828-29 (Raleigh: Lawrence \& Lemay, 1829), chap. cxxvi.

${ }^{31}$ Laws of North-Carolina, 1794 (Halifax: Hodge \& Willi [sic], n.d.), chap. xcv, in Session Laws of American States (microfiche, N.C. State Library). Roy Parker, A Brief History of Cumberland County (Raleigh: Division of Archives and History, N.C. Dept. of Cultural Resources, 1990), 36-37. (Just to clarify, the first library in North Carolina was donated by the Society for the Propagation of the Gospel in Foreign Parts to Bath in 1700; the first community or subscription library was the Cape Fear [Wilmington] Library Society founded in 1760; the first tax-supported public library was Durham's in 1897.)

${ }^{32}$ Laws of North Carolina 1818 (microfiche, N.C. State Library); Cumberland County Misc. records, Fayetteville Library Company, no date, State Archives; Laws of the State of North Carolina, passed ... 1840-41 (Raleigh: W. R. Gales, 1841), chap. vii.

${ }^{33}$ Cross Creek Lodge I.O.O.F, SHC (originals in the Cumberland County Public Library). See also Jerry A. Thrasher, "History of the Cumberland County Public Library \& Information Center" (typescript, Cumberland County Public Library files, 1985); and Arthur C. Jenkins III, "A Public Library for Fayetteville, North Carolina" (thesis, Clemson University School of Architecture, 1970).

${ }^{34}$ Elizabeth Moore, Records of Craven County North Carolina (Bladenburg, Md: Genealogical Recorders, 1960), 1:77-81, 177; "Literature of North Carolina," Monthly Anthology and Boston Review 3 (July 1806), 355-57, excerpted in Libraries in American Periodicals Before 1876, 252; Virginia Ellis Gibson, "Salmon Hall: North Carolina Printer, 1800-1840," (master's thesis, University of North Carolina at Chapel Hill, 1967), 29-30; and Alan D. Watson's well-crafted and researched A History of New Bern and Craven County (New Bern: Tryon Palace Commission, 1987), 178. See also William L. Saunders, ed., The Colonial Records of North Carolina, 10 vols. (Raleigh: State of North Carolina, 1886-1890), esp. v. 7, 35-36, 98-99, 104, 689; v. 9, 238-43, 245-48, 304-06.

${ }^{35}$ Moore, Records of Craven County, 89; Gibson, "Salmon Hall," 30. Stephen F. Miller remembered Hall as a "courteous" man but little else. "Recollections of Newbern," Our Living and Our Dead... 1 (November 1874): 452. The Georgetown Library Society in South Carolina was also spearheaded by a printer. Frances Lander Spain, "Libraries of South Carolina: Their Origins and Early History, 1700-1830," Library Quarterly 17 (1947): 36

${ }^{36}$ Newbern Library Company, State Archives. In the 1820s eastern publishers introduced cheap cloth-covered casings that sharply reduced the business of local bookbinders. Manufactures of the United States in 1860 ... Eighth Census (Washington: Government Printing Office, 1865): cxliii-cxlv; Richard W. Clement, Books on the Frontier: Print Culture in the American West 1763-1875 (Washington: Library of Congress, 2003), 35. Bookbinders, like printers, had the opportunity to read widely.

${ }^{37}$ Acts Passed by the General Assembly of the State of North-Carolina ... 1827-28 (Raleigh: Bell \& Lawrence, 1828), cxli; Acts Passed by the General Assembly of the State of North Carolina ... 1833-34 (Raleigh: Lawrence \& Lemay, 1834), chap. lxv. Griffith A. Hamlin, "Educational Activities of the Disciples of Christ in North Carolina, 1852-1902," NCHR 33 (July 1956): 317; James M. Creech, History of Greene County, North Carolina (Baltimore: Gateway Press, 1979), 512. Dorothy Lloyd Gilbert, Guilford: A Quaker College (Greensboro: Guilford College and New Garden Boarding School, 1937), 27; D. H., "Reminiscences of New 
Garden Boarding School in 1895," Guilford Collegian 8 (September 1895): 6-7; and W. A. Bryan, "Some Social Traits of the Rich Square Quakers, with New Garden Document," Trinity College Historical Papers 8 (1908): 6-14.

${ }^{38}$ Laws of the State of North-Carolina, passed ... 1819 (Raleigh: Thomas Henderson Jr., 1820), cv.

${ }^{39}$ DNCB, s.v. "Swaim, William" (quotation). Cf., Patrick Sowle, "The North Carolina Manumission Society, 1816-1834," NCHR 42 (January 1965), 62-63; Thad Stem Jr., The Tar Heel Press (Charlotte: N.C. Press Association, 1973), 33-35; Marjorie Whittington Memory, "A History of the Randolph Public Library, 1935-1967" (master's thesis, University of North Carolina at Chapel Hill, 1968); and Larry E. Sullivan, "The Reading Habits of Nineteenth-Century Baltimore," in Donald G. Davis Jr., ed., Libraries \& Culture (Austin: University of Texas Press, 1981), 227-40. Bibliophile William Henry Harrison Beard also lived in the Deep River area until the Civil War. Peter A. Soderbergh, "Charles A. Beard, the Quaker Spirit, and North Carolina," NCHR 46 (January 1969): 21-22.

${ }^{40}$ Providence: Acts Passed by the General Assembly of the State of North Carolina ... 1834-35 (Raleigh: Philo White, 1835), chap. xliv. See also Ernest Trice Thompson, Presbyterians in the South, 3 vols. (Richmond: John Knox Press, 1963), 1:64, 246; Daniel Augustus Tompkins, History of Mecklenburg County and the City of Charlotte from 1700 to 1903 (Charlotte: Observer Print House, 1903), 74, 111.

${ }^{41}$ Laws of the State of North Carolina, passed ... 1852 (Raleigh: Wesley Whitaker, Jr., 1853), chap. lxvii; and "Letters Patent. Literary Institutions and Benevolent and Charitable Societies." Governor's Office, Charters, 1853-1864, State Archives.

42 "Intellectual Food for the Children of the City," Wilmington Messenger, 1858 (undated typescript), New Hanover Public Library; William J. Rhees, Manual of Public Libraries, Institutions, and Societies, in the United States ... (Philadelphia: J.B. Lippincott, 1859), 626-27; “Dedication Wilmington Light Infantry Memorial Library” (pamphlet, 16 July 1956), New Hanover Public Library file DB: PL 2 (quotation); Rehder, "Development of Libraries in the Lower Cape Fear," unpaginated; Wetmore, "Literary and Cultural Development of Ante-Bellum Wilmington," 45-47, 162. See also McMullen, American Libraries before 1876, 70-72; Thompson, Evolution of the American Public Library, 80-95; and Thomas Augst, The Clerk's Tale: Young Men and Moral Life in Nineteenth-Century America (Chicago: University of Chicago Press, 2003).

${ }^{43}$ Jane Wood, “The Old Library and New” undated newspaper clipping, librarian's scrapbook, New Hanover County Public Library (quotations). See also James A. Secord, Victorian Sensation: The Extraordinary Publication, Reception, and Secret Authorship of 'Vestiges of the Natural History of Creation' (Chicago: University of Chicago Press, 2003 ed.); John E. Buschman, Dismantling the Public Sphere: Situating and Sustaining Librarianianship... (Westport, Conn.: Libraries Unlimited, 2004), esp. 3-35; and Ari Kelman, "The Sound of the Civic: Reading Noise at the New York Public Library," in Augst and Wiegand, The Library as an Agency of Culture, 26-28.

${ }^{44}$ The Seventh Census of the United States: 1850 (Washington: Robert Armstrong, 1853); University of Virginia, Geospatial and Statistical Data Center. United States Historical Census Data Browser: http://fisher.lib.virginia.edu/census/, September 2, 2004.

${ }^{45}$ Wells, Origins of the Southern Middle Class, 106 (quotation). See instead Robert V. Williams's important but neglected "Public Library Development in the United States, 1850-1870: An Empirical Analysis," in Davis, Libraries, Books \& Culture, 177-201.

${ }^{46}$ Population of the United States in 1860 (Washington: Government Printing Office, 1864); University of Virginia, Geospatial and Statistical Data Center. United States Historical Census Data Browser: http://fisher.lib.virginia.edu/census/, September 2, 2004.

${ }^{47}$ Lewis P. Simpson, Mind and the American Civil War: A Meditation On Lost Causes (Baton Rouge: Louisiana State University Press, 1989), 50 (quotation). For ratios of libraries to population, see McMullen, American Libraries before 1876, 46, 50-53, and tables 3.3 and 3.4. See also http://www.princeton.edu/ -davpro/databases/index.html.

${ }^{48}$ Adapted from McMullen, American Libraries before 1876, table 3.3.

${ }^{49}$ Nye, Society and Culture in America, 33; O'Brien, Re-Thinking the South, 1-56; Powell, North Carolina Through Four Centuries, 335-38. The development of a mass national book market had a negative effect on local printing.

${ }^{50}$ See also Paul Starr, The Creation of the Media: Political Origins of Modern Communications (New York: Basic Books, 2004), 124-30; Rose, Voices of the Marketplace, 180-82; Robert H. Wiebe, The Opening of American Society: From the Adoption of the Constitution to the Eve of Disunion (New York: Vintage, 1984), 353-75; Mary P. Ryan, Civic Wars: Democracy and Public Life in the American City during the Nineteenth Century (Berkeley: University of California Press, 1997); and Marc Harris, "Civil Society in Post-Revolutionary America," in Eliga H. Gould and Peter S. Onuf, eds., Empire and Nation: The American Revolution in the Atlantic World (Baltimore: John Hopkins University Press, 2005), 197-216. 